\title{
CIVIL ACADEMIC EDUCATION OF HELICOPTER ENGINEERING IN POLAND
}

\section{W. Lucjanek} Institute of Aeronautics and Applied Mechanics of Warsaw University of Technology. E-mail: wluc@meil.pw.edu.pl
Received 2711 2002; accepted 26022004

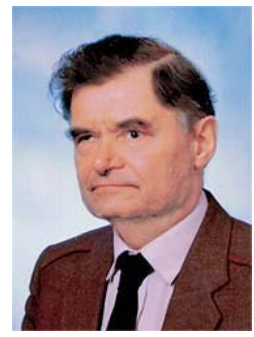

\begin{abstract}
Wieslaw LUCJANEK (1934). Graduated from Warsaw University of Technology (WUT): MSc (Aero Engineering) 1957, PhD 1964. Since 1956 with WUT. 1965/66-post doctorate fellow, National Research Council of Canada. Since 1970 associate professor. 1971-75 Deputy Dean, Faculty of Power and Aeronautical Engineering (FPAE), 1975-78 Dean, FPAE. Since 1979 Head, Helicopter Mechanics Research Team, Institute of Aeronautics and Applied Mechanics (IAMM), WUT. 1984-87 Professor, University of Tripoli, Libya. 1988-99 Head, Department of Avionics and Systems, IAMM. Since 1999 Expert of EC. Since 2000 retired and till 2002 employed half time at WUT. Author or co-author of 5 books, 3 textbooks, and more than 60 papers published in Polish and international journals and symposia proceedings, concerning: Aerodynamics, Aero elasticity, Airscrews, Education, Flight Mechanics, Rotorcraft Aeromechanics, Mechanics, and Technical Diagnostics. Treasurer of STAR/Poland (Polish branch of European association "Specialised Training in Aeronautics and Research"), co-creator of Polish Rotorcraft Association, President of Poland Chapter of the American Helicopter Society (AHS).
\end{abstract}

\begin{abstract}
Requirements of industry, research centres, and users necessitate the teaching of helicopter engineering at various levels and specialities, both in the civil and military sectors in Poland. Civil academic education of helicopter engineering has been offered for many years at the Faculty of Power and Aeronautical Engineering (FPAE) of Warsaw University of Technology (WUT) on undergraduate and graduate levels. For the past last years the Faculty of Mechanical Engineering (FME) of Lublin Technical University (LTU) has also conducted education in helicopter engineering, mostly focused on airframe design and manufacturing, since a helicopter factory is located nearby.

In this paper, education at WUT and LTU is described, and examples of themes of selected student courses and diploma projects, as well as $\mathrm{PhD}$ theses, are presented.
\end{abstract}

Keywords: education, helicopter engineering.

\section{Introduction}

Aviation and aeronautics have a long tradition in Poland. The first flight took place in 1909, and the first airplane factory, built in Warsaw, began production on 17 June 1911.

Throughout the twenties and thirties of the $\mathrm{XX}^{\text {th }}$ centuries, several aircraft factories were built and many types of both civil and military aircraft were designed and produced. Polish pilots were quite successful in many international competitions.

World War II practically stopped the development of Polish aeronautical industry, although many designers, engineers, and scientists emigrated and worked, often very successfully, in the aircraft industries and research organizations of other (allied) countries.

At the end of hostilities, the Polish aircraft industry was reborn, and by 1946 a new generation of airplanes and gliders had been designed and built.

Currently, aircraft manufacturing takes place at a number of locations across Poland. Helicopter airframes are manufactured by PZL-Świdnik, at a factory located about 180 kilometres southeast of Warsaw. Helicopter engines and transmissions are produced in Rzeszow, an industrial town located about 250 kilometres south of
Warsaw. Most of the research and some of the design work is undertaken at centres located in Warsaw.

Poland is one of not many countries with its own helicopter industry. The first helicopter designed and produced in Poland, the $B \dot{Z}-1$ (GIL), had its maiden flight on 4 April 1950, and the helicopter factory PZL-Świdnik celebrated its $50^{\text {th }}$ anniversary in 2001. During its half a century of activity, the factory has manufactured thousands of helicopters. Initially it produced the Russian models $M i-1$ and $M i-2$, which were then improved and modified in the factory. The factory finally began to manufacture its own designs, among which $W-3$ "Sokót" and $S W-4$ are the most commonly known. Moreover, the testing of prototype systems $I S$-2, a light, 2-seat helicopter is in progress in the Aviation Institute in Warsaw.

\section{University Offers Needs of Education}

Requirements of industry, research centres, and users necessitate the teaching of helicopter engineering at various levels and specialities, both in the civil and military sectors. Civil academic education of helicopter engineering has been offered at Faculty of Power and Aeronautical Engineering (FPAE) of Warsaw University of Technology (WUT) on undergraduate and graduate levels for many years. It addition to theoretical approaches, like aeromechanics and flight mechanics, 
students may choose power plants, avionics and systems, principles of airframe design and manufacturing, and general treatment of aircraft utilisation and service.

For the past few years the Faculty of Mechanical Engineering (FME) of Lublin Technical University (LTU) has also conducted education in helicopter engineering on undergraduate and graduate levels, mostly focused on airframe design and manufacturing, since a helicopter factory and civil multi-purpose helicopter operator are located nearby.

\section{Programmes of Education}

Both WUT and LTU are national schools controlled by Ministry of National Education and Sport (MNES). Under current legislation, education is performed within directions of study, which are divided into specialties, and further into diploma paths, consisting of blocks of subjects corresponding to diploma themes. A considerable portion of the subjects is obligatory, but there are also elective subjects. Obligatory subjects are mostly associated with the faculty and direction of study. Some are also associated with the specialty, and few are connected with the diploma path. A student and a diploma advisor usually agree upon the diploma theme, and a set of elective subjects is matched to the theme of the diploma. At both universities, Helicopter Engineering is placed within the direction of study Mechanics and Design of Machines, and the academic year commences on 1 October and terminates on 30 September.

WUT, Faculty of Power and Aeronautical Engineering (FPAE)

At FPAE the following types of study are offered: Undergraduate

- $\quad$ four-year, leading to the Engineer (equivalent to BSc) diploma,

- $\quad$ five-year, leading directly to the MSc diploma. Postgraduate

- 1.5-year, leading to the MSc diploma, for persons having a BSc diploma,

- three-four-year, leading to the $\mathrm{PhD}$ degree, for persons having an MSc diploma.

At FPAE the direction of study is divided into several specialties, one of them is Aeronautics ${ }^{1}$, which is further divided into diploma paths. Numbers and names of diploma paths may vary from academic year to year, according to the number of students interested in choosing them. The list of diploma paths must to be conducted in the middle of the second year of student education, because the diversification on specialties and then on diploma paths begins since fourth semester ${ }^{1}$. The

1 At the time of writing this paper, changes of structure of education at FPAE are under consideration by the Faculty Council, and some alterations of the data presented are possible. For instance, attempts are being undertaken to open a new direction of study called Aeronautics and Cosmonautics example list of diploma paths offered within specialty Aeronautics is as follows:

- Aeronautical Equipment (Avionics and Systems)

- Astronautics

- Aeronautical Power Plants,

- Construction and Exploitation of Airplanes,

- Helicopters. below.

Structure of education can be illustrated as shown

\section{UNIVERSITY}

FACULTY

\section{Direction of study}

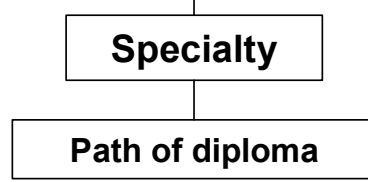

The four-year undergraduate programme leading to an engineering degree consists of the following blocks of subjects:

Table 1. Undergraduate programme

\begin{tabular}{|l|c|}
\hline \multicolumn{1}{|c|}{ Subject(s) } & $\mathbf{h} / \mathbf{w}^{\mathbf{2}}$ \\
\hline $\begin{array}{l}\text { Basic General (mathematics, physics, } \\
\text { informatics, etc.) }\end{array}$ & 26 \\
\hline $\begin{array}{l}\text { Basic Technical (mechanics, thermodynamics, } \\
\text { electricity, manufacturing, etc.) }\end{array}$ & 52 \\
$\begin{array}{l}\text { Of direction of study, specialty, and path of } \\
\text { diploma, Course Project, Elective } \\
\text { (in the number above elective subjects } \geq 7\end{array}$ & 82 \\
h/w) & \\
$\begin{array}{l}\text { Humanities, economy, ecology } \\
\text { Foreign Languages }\end{array}$ & 6 \\
\hline $\begin{array}{l}\text { Diploma Seminar } \\
\text { Diploma Project }\end{array}$ & 14 \\
\hline Total (without physical education) & $\mathbf{1 9 8}$ \\
\hline
\end{tabular}

Physical education is provided in three to eight 8 semesters, two $\mathrm{h} / \mathrm{w}$.

To obtain an engineering degree, the following conditions have to be fulfilled:

- $\quad$ Collecting at least 210 credits $^{3}$ and successfully completing all obligatory subjects,

- $\quad$ Completing 4 weeks of practical training (during the $8^{\text {th }}$ semester),

- $\quad$ Completing a diploma project and successfully passing the diploma examination.

For the specialty Aeronautics the following subjects, $(\mathrm{h} / \mathrm{w})=$ two each, are obligatory:

${ }^{2} \mathrm{~h} / \mathrm{w}$ - hours per week. The total number of hours per subject(s) is $(\mathrm{h} / \mathrm{w}) \times 15$ weeks per semester.

${ }^{3}$ Depending on the subject, the number of credits is equal to or greater than $\mathrm{h} / \mathrm{w}$ and equal to 30 per semester. 
Table 2. Subjects of Aeronautics specialty

\begin{tabular}{|c|}
\hline Subject \\
\hline Aerodynamics \\
\hline Aeronautical Materials \\
\hline Aeronautical Power Plants \\
\hline Aeroplanes, Helicopters, Gliders \\
\hline Astronautics \\
\hline Avionics \\
\hline Construction of Aeronautical Piston and Turbine Engines \\
\hline Design of Aeroplanes \\
\hline Flight Mechanics \\
\hline Method of Finite Elements I \\
\hline On-board Systems \\
\hline Performances of Aeroplanes \\
\hline $\begin{array}{l}\text { Selected Topics of Strength of Materials and } \\
\text { Constructions }\end{array}$ \\
\hline Strength of Aeronautical Constructions \\
\hline Elective $(\mathrm{h} / \mathrm{w} \geq 6)$ \\
\hline
\end{tabular}

Helicopters, or more generally Rotorcraft, two elective subjects are offered $(\mathrm{h} / \mathrm{w})=$ two each:

- Fundamentals of Rotorcraft Construction,

- Rotorcraft Aeromechanics,

and the possibility of performing a course project, diploma seminar and diploma project related to rotorcraft technology.

Students interested in obtaining an MSc diploma directly, without an engineering diploma, can speed up their education by choosing (in $8^{\text {th }}$ semester) subjects provided for the MSc course instead of engineering diploma seminar and engineering diploma project. That gives them the chance to complete MSc study (undergraduate) five years. For those who completed four-year undergraduate study and obtained an engineering diploma, the 1.5 -year postgraduate study leading to an MSc degree is offered.

The postgraduate programme of, 1.5-years of study leading to the MSc degree, consists of the following subjects:

Table 3. Postgraduate programme

\begin{tabular}{|l|l|l|}
\hline Subjects obligatory for all students of the FPAE & $h / w$ \\
\hline
\end{tabular}

\begin{tabular}{|l|c|}
\hline Mathematics I & 3 \\
\hline Mathematics II & 4 \\
\hline Physics & 3 \\
\hline Humanities & 2 \\
\hline Diploma Seminar & 3 \\
\hline Diploma Project & 20 \\
\hline \multicolumn{1}{|c|}{ Subjects obligatory for direction of study } & $\mathbf{h} / \mathbf{w}$ \\
\hline Aerodynamics I & 3 \\
\hline Control of Aircraft & 3 \\
\hline Heat Flow & 2 \\
\hline $\begin{array}{l}\text { Selected Topics of Fundamentals of Machine } \\
\text { Design }\end{array}$ & 2 \\
\hline $\begin{array}{l}\text { Static, Stability and Vibrations of Thin-Wall } \\
\text { Constructions }\end{array}$ & 2 \\
\hline Transport of Energy & 2 \\
\hline Vibration of Aeronautical Constructions & 2 \\
\hline
\end{tabular}

\begin{tabular}{|l|c|}
\hline \multicolumn{1}{|c|}{ Subjects obligatory for specialty } & h/w \\
\hline Aerodynamics II & 1 \\
\hline Avionics and On-Board Systems & 3 \\
\hline Contemporary Aeronautical Power Plants & 3 \\
\hline Cosmic Technologies & 3 \\
\hline Course Project & 4 \\
\hline Exploiting of Aircraft Systems & 2 \\
\hline Flight Dynamics & 3 \\
\hline $\begin{array}{l}\text { Method of Finite Elements II (Aeronautical } \\
\text { Applications) }\end{array}$ & 3 \\
\hline Optimising in Design of Aircraft & 3 \\
\hline Unmanned Flying Vehicles & 3 \\
\hline
\end{tabular}

Elective Subjects

At this study diploma paths are based only on elective subjects, the diploma seminar, and the diploma project. Education in rotorcraft engineering is also offered.

For students having an engineering or equivalent diploma obtained outside the FPAE, some alterations of this programme are possible, depending on their interests and the subjects they have already completed.

To obtain an MSc degree, the following conditions have to be fulfilled:

- $\quad$ Collecting at least 90 credits and successfully completing all obligatory subjects,

- Completing four weeks of practical training if not performed during undergraduate study,

- $\quad$ Completing a diploma project and successfully passing the diploma examination.

Study leading to a $\mathrm{PhD}$ degree is based mostly on research. Students are obliged to assist in some teaching work (to conduct tutorials or/and laboratory work), 60120 hours per year. Some of them voluntarily attend lectures and/or seminars either offered particularly to them or provided for other types of study.

Lectures, tutorials, seminars, and projects are performed at the university, but some laboratories are located at other places in Warsaw: the Institute of Aviation (industrial aeronautical research centre), the Technical Base of Polish Airlines "LOT", and an aeroplane factory.

\section{LTU, Faculty of Mechanical Engineering (FME)}

At the time of writing this paper, the following types of study are offered at the FME:

Undergraduate

- $\quad$ five-year, leading to an MSc diploma.

Postgraduate

- three-four year, leading to the $\mathrm{PhD}$ degree, for persons having an MSc diploma.

- Undergraduate courses leading to the Engineer (equivalent to $\mathrm{BSc}$ ) degree and postgraduate

${ }^{4}$ Only for students not performing engineering diploma seminar and diploma project. 
leading to the MSc degree for persons having a BSc diploma are under consideration.

Helicopter engineering is offered as a specialty called Helicopter Construction. Diploma paths are based only on elective subjects, diploma seminar, and diploma project. In addition to common to mechanical engineering, the following subjects are obligatory for the specialty:

Table 4. Subjects of Helicopter Construction specialty

\begin{tabular}{|l|c|}
\hline \multicolumn{1}{|c|}{ Subjects obligatory for specialty } & h/w \\
\hline Aerodynamics & 3 \\
\hline Aeronautical Power Plants & 3 \\
\hline Computer Aided Helicopter Design & 2 \\
\hline Course Project I & 3 \\
\hline Course Project II & 3 \\
\hline Diploma Project - 25 credits & \\
\hline Diploma Seminar & 2 \\
\hline Exploiting of Helicopters & 2 \\
\hline Fundamentals of Aeronautics & 6 \\
\hline Helicopter Design & 3 \\
\hline Helicopter Equipment and Systems & 2 \\
\hline Helicopter Fatigue & 2 \\
\hline Helicopter Flight Dynamics & 3 \\
\hline Helicopter Manufacturing & 3 \\
\hline Helicopter Vibrations & 3 \\
\hline Practical Training - 19 credits & 2 \\
\hline Strength of Aeronautical Constructions & \\
\hline Technology of Helicopter Assembling & \\
\hline
\end{tabular}

Elective Subjects 9

Two companies associated with helicopters are located close to LTU: the helicopter factory PZL Świdnik and civil multi-purpose helicopter operator HELISECO. Some laboratories are located there. This also facilitates the placement of students for practical training and the selection of topics for course projects and diploma projects dealing with practical problems arising in both companies. Moreover, cooperation of the university with these enterprises creates a good opportunity for establishing a centre for certification of helicopter maintenance staff, fulfilling the Joint Aviation Requirements JAR-66 and JAR-147. Such an activity is under consideration.

\section{Examples of Themes of Student Projects ${ }^{5}$, Including PhD Theses}

\section{Course projects (FPAE)}

- Inverse Simulation in Analysis of a Helicopter Control (1995).

- Influence of Helicopter Fuselage Pitching in Hover on the Main Rotor Blade Flapping (1996).

\footnotetext{
${ }^{5}$ Both course and diploma projects at both WUT and LTU are related to five-year undergraduate study leading to an MSc degree.
}

Systems of Directional Balancing, Stabilising and Controlling of One-Main Rotor Helicopters (1997).

- $\quad$ Simplified Models of Hinge less Helicopter Rotors for Analysis of Blade Flapping (2000).

- Computer Code for Calculation of Helicopter Performances (2002).

\section{Course projects (FME)}

Calculation of Performances of Hypothetical Helicopter (2000).

Elaboration of Dynamical Model and Performing Computer Simulation of Vibration Eliminator for Lifting Rotor Head of Selected Helicopter (2000). Elaboration of Manufacturing Process of threelayer Composite Plate with Nomex Type Filler (2000).

Identification of Tail Boom and Tail Rotor Vibrations by Ground Tests (2000).

Optimisation of the "SW-4" Helicopter Tail Rotor Blades Geometry Considering Selected Design and Exploiting Criteria (2000).

\section{Diploma projects (FPAE)}

Conceptual Project of a HUMS Helicopter (1994). Project Study of the Tail Rotor for an Ultra Light Helicopter (1995).

Two-Seat Multi-Role Helicopter with Two SmallPower Turbine Engines (1996).

Conceptual Project of Shrouded Tail Rotor for the "SW-4" Helicopter (1997).

Conceptual Project of a Simulator of Aeronautical Diagnostic Systems (1998).

\section{Diploma projects (FME)}

- Conceptual Project of a Simplified Main Rotor head for "SW-4" Helicopter (2001).

- Design of a Folded Tail Boom for the PZL W3 "Sokół” Helicopter (2001).

- Design of Retracted Undercarriage for the PZL W3 "Sokół” Helicopter (2001).

- Design of the PZL W3 "Sokó1" Helicopter Automatic Anchoring System on the Board of a Corvette (2001).

- $\quad$ Design of a Small Unmanned Helicopter (2002).

\section{PhD theses (FPAE)}

- Stability of Motion of Helicopter-Lifting-Rotor Blades in Steady Flight (1978).

- Dynamic Stability of a Single-Lifting-Rotor Helicopter with Slung Load (1980).

- Application of the Attitude and Navigation System in Evaluation of Helicopter Flying Qualities (under way). 
- Control of Tilt rotor Vehicle in Selected Flight Stages (under way).

\section{International Student Exchange}

Both FPAE and FME participate in student exchange within the European Credit Transfer System (ECTS) in the framework of the Socrates and Leonardo programmes. Although teaching is conducted mainly in Polish, some subjects are also offered in English. This means that foreign students can earn credits in Poland and courses successfully completed will be recognised at their home universities and will count towards their final award.

Information about WUT and the FPAE as well as LTU and the FME is available on the Internet [1-4].

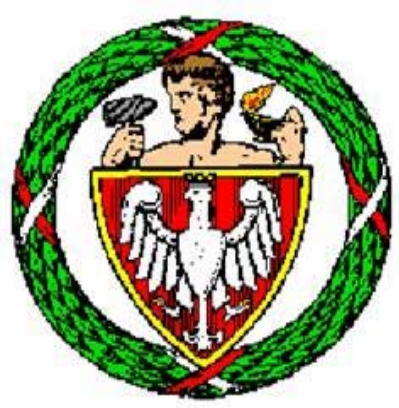

Fig 1. Warsaw University of Technology http://www.pw.edu.pl

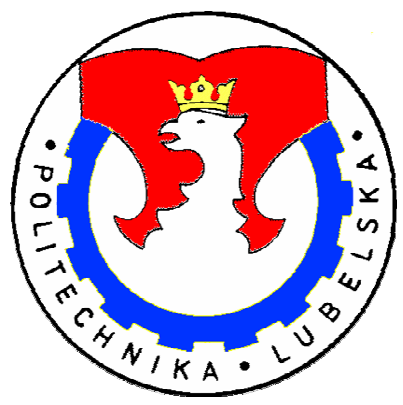

Fig 3. Lublin Technical University http://www.pol.lublin.pl

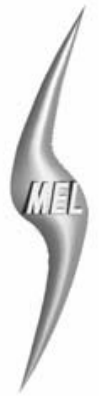

Fig 2. Faculty of Power and Aeronautical Engineering http://www.meil.pw.edu.pl

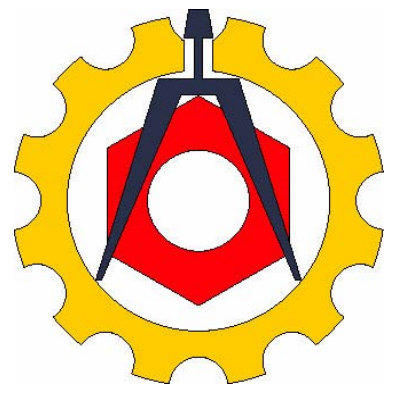

Fig 4. Faculty of Mechanical Engineering

http://archimedes.pol.lublin.pl

\section{Concluding Remarks}

Two Polish civil educational institutions offer education and research in rotorcraft engineering.

At the Faculty of Power and Aeronautical Engineering (FPAE), Warsaw University of Technology (WUT), three levels of education are available:

- Undergraduate, leading to an Engineering (equivalent to $\mathrm{BSc}$ ) diploma,

- Undergraduate, leading directly to an MSc diploma,

- $\quad$ Postgraduate, leading to an MSc diploma,

- $\quad$ Postgraduate, leading to a $\mathrm{PhD}$ degree.

Students may choose theoretical approaches to rotorcraft technology, like aeromechanics and flight mechanics, as well as power plants, avionics and systems, principles of airframe design and manufacturing, and general treatment of aircraft utilisation and service.

At the Faculty of Mechanical Engineering (FME), Lublin Technical University (LTU), two levels of education are available:

- Undergraduate, leading directly to MSc diploma,

- $\quad$ Postgraduate, leading to $\mathrm{PhD}$ degree,

mostly focused on airframe design and manufacturing, since a helicopter factory, and civil multipurpose helicopter operator are located nearby.

Participation of LTU in establishing a centre for certification of helicopter maintenance staff, fulfilling the Joint Aviation Requirements JAR-66 and JAR-147, is under consideration.

Both universities take part in European Credit Transfer System (ECTS) that makes possible international exchange of students.

\section{References}

1. Website: http://www.pw.edu.pl

2. Website: http://www.meil.pw.edu.pl

3. Website: http://archimedes.pol.lublin.pl

4. Website: http://www.pol.lublin.pl 